\title{
Perceived Constraints Affecting the Desired Performance of MGNREGA and Strategies for Improvement
}

\author{
Khumukcham Stina ${ }^{1 *}$, L. Devarani ${ }^{2}$, A. Sarkar ${ }^{3}$, Ram Singh $^{2}$ and R.J. Singh ${ }^{2}$ \\ ${ }^{1} M T T C$ \& VTC, College of Agriculture, Central Agricultural University, Imphal, Manipur, India \\ ${ }^{2} S c h o o l$ of Social Sciences, College of Post Graduate Studies, Central Agricultural University, Umiam, Meghalaya, India \\ ${ }^{3}$ Department of Extension and Social Sciences, College of Fisheries, Central Agricultural University, Lembucherra, Tripura, India
}

*Corresponding author: stinaluwang.cpgs@gmail.com (ORCID ID: 0000-0002-0588-7945)

Received: 15-02-2021

Revised: 24-04-2021

Accepted: 27-05-2021

\begin{abstract}
Mahatma Gandhi National Rural Employment Guarantee Act (MGNREGA) was implemented by Government of India (GOI) with the objective of enhancing livelihood security in rural areas by providing at least 100 days of guaranteed wage employment resulting in the creation of durable assets. Despite of the fact that huge allocations have been made by the central government for alleviation of poverty through MGNREGA, the standard of living of the people has not improved to the desired extent, and the employment opportunities for the youths are few and far between. Hence, it becomes imperative to identify the antecedent factors which unable to comply with the promises made during their introduction. The present study was conducted in the Imphal East and Churachandpur districts of Manipur. The data were collected from 108 respondents (100 were beneficiaries \& 8 were functionaries of MGNREGA). The findings revealed that non-availability of 100 days of work, late payment of wages, underpayment of wages, non-availability of tools \& worksite facilities etc. were the constraints perceived by the beneficiaries. While, constraints perceived by the functionaries of MGNREGA were scarcity of funds and non-acceptance of labor budget, failing to upload Management Information System (MIS) report timely and low Information Education Communication (IEC) campaign.
\end{abstract}

\section{HIGHLIGHTS}

0 Despite the fact MGNREGA was primarily implemented for enhancing livelihood security in rural areas by providing 100 days wage employment.

(0 Various constraints were perceived by the beneficiaries as well as functionaries of MGNREGA, which hamper the performance. To counteract the constraints, various suggestions were also provided by the respondents.

Keywords: MGNREGA, constraints, suggestion, beneficiaries and functionaries

Even as India continues to record impressive growth rates, poverty remains widespread and disparities deeply entrenched. According to the UNDP 2011 Global Human Development Report, India is ranked 134 in poverty out of 187 countries and UN-recognized territories. In India, chronic poorness is due to sustained experiencing significant capability deprivations, and thus, the poor often pass on their poverty to subsequent generations (Hulme and Shepherd, 2003). Absolute poverty refers to subsistence below a minimum socially acceptable living condition (Mabughi and Selim, 2006). A

How to cite this article: Stina, K., Devarani, L., Sarkar, A., Singh, R. and Singh, R.J. (2021). Perceived Constraints Affecting the Desired Performance of MGNREGA and Strategies for Improvement. Int. J. Soc. Sci., 10(02): 127-132. Source of Support: None; Conflict of Interest: None (क) 
person is considered to be in absolute poverty if his or her consumption or income level falls below some minimum level necessary to meet basic needs (World Bank, 2000). The primary reason for poverty is unemployment. In India, unemployment is mainly due to the shortage of capital, the poor exploitation of natural resources, and inadequate employment opportunities. GoI, 2013 reported that the country's overall unemployment rate is $(4.7 \%)$. Unemployment rate in a rural area is $(4.4 \%)$ whereas in urban areas, it is $(5.7 \%)$. Although the Government of India had initiated determined efforts through several plans and measures to alleviate poverty in rural India, there remained much more to be done to bring prosperity in the lives of the people in rural areas (Kaushik, 2007). Due to the failure of various programs to achieve the targeted objectives laid down in the time of its implementation, there has been a rationalization and merger of the programmes and specific other changes. As a result, MGNREGA came into being on February $2^{\text {nd }}$, 2006, under the Government of India, Ministry of Rural Development to enhance livelihood security in rural areas by providing at least 100 days of guaranteed wage employment in the creation of durable assets. Despite the fact that huge allocations have been made by the central government for alleviation of poverty through MGNREGA, having the potential to transform the rural socio-economic relations at micro-individual as well as macro-societal levels. However, it could be observed that MGNREGA cannot be a long-term solution to the unemployment problem of rural India, and it has not succeeded in creating sufficient productive assets for strengthening rural infrastructure. It has, therefore, failed to make a significant impact on the existing socioeconomic conditions of poor rural households (Singh, 2012). Hence, it becomes imperative to identify the problems/shortcomings of this program which lead to an unsatisfactory result and unable to comply with the promises made during their introduction.

\section{DATABASE AND METHODOLOGY}

The present study was conducted adopting the ex post facto research design. The study was conducted in the state of Manipur, one valley and one hill district viz. Imphal East and Churachandpur, respectively. Since the state-wise poverty estimates of 2011-12 (Planning Commission, 2013) were indicative that Manipur was one of the highest-ranked states in India in terms of poverty ratio. Data were collected from a total of 100 beneficiaries based on probability proportionate to size sampling. Further, based upon availability/willingness to cooperate, 8 numbers of various levels of state, districts, blocks, and GP functionaries associated with the implementation of MGNREGA were included in order to gain further insight into the existing situation. Thus, the primary data collection was made on altogether 108 respondents.

In accordance with the specific requirements to draw logical conclusions, analyses and interpretation of collected data were done by utilizing appropriate statistical tools.

\section{Frequency and percentage}

Frequency was used to know the distribution pattern of respondents according to a variable. For making comparisons, the percentage values were calculated by dividing the frequency of a particular cell by the total number of respondents in a particular category and multiplying by 100 .

\section{Garrett ranking}

The ranking is an expression of people's priority about their thoughts and feelings. Garrett ranking was used in ranking the constraints hampering the adequate performance of the programs as expressed by the beneficiaries. The formula for percent position, as suggested by Garrett (1979) is:

Percent position $=\frac{100(R-0.5)}{N}$

Where $R=$ the rank of the individual item in the series $N=$ number of individual items ranked

\section{RESULTS AND DISCUSSION}

\section{Constraints of MGNREGA perceived by the respondents}

The constraints perceived by the beneficiaries of 
Perceived Constraints Affecting the Desired Performance of MGNREGA and Strategies for Improvement $\mathbb{J}_{\text {AESSRA }}$

MGNREGA that affect the program's desired performanc are listed and ranked according to their perceived importance in Table 1. Constraints expressed by the functionaries of the program are presented in Table 2.

Table 1: Constraints perceived by the beneficiaries affecting desired performance of MGNREGA $(n=100)$

\begin{tabular}{|c|c|c|c|c|}
\hline $\begin{array}{l}\text { S1. } \\
\text { No. }\end{array}$ & Statements & $\begin{array}{l}\text { Total } \\
\text { Score }\end{array}$ & $\begin{array}{l}\text { Mean } \\
\text { Score }\end{array}$ & Rank \\
\hline 1 & Non availability of 100 days of work & 4150 & 83 & 1 \\
\hline 2 & Late payment of wages & 3650 & 73 & 2 \\
\hline 3 & Under payment of wages & 3300 & 66 & 3 \\
\hline 4 & $\begin{array}{l}\text { Tools, material and worksite } \\
\text { facilities not provided }\end{array}$ & 2761 & 55.22 & 4 \\
\hline 5 & $\begin{array}{l}\text { Selection of less priority or } \\
\text { inappropriate work }\end{array}$ & 2046 & 40.92 & 8 \\
\hline 6 & No solution to complain or query & 2416 & 48.32 & 5 \\
\hline 7 & $\begin{array}{l}\text { Oral application or request for work } \\
\text { being made as an excuse for denial } \\
\text { of work on time }\end{array}$ & 2415 & 48.3 & 6 \\
\hline 8 & $\begin{array}{l}\text { Job Card and bank passbook with } \\
\text { the implementing authority at grass } \\
\text { root level. }\end{array}$ & 2335 & 46.7 & 7 \\
\hline 9 & No records entered in job card & 1863 & 37.26 & 11 \\
\hline 10 & $\begin{array}{l}\text { Unemployment allowance not } \\
\text { provided }\end{array}$ & 2005 & 40.1 & 9 \\
\hline 11 & $\begin{array}{l}\text { Non acceptance of written work } \\
\text { application }\end{array}$ & 1186 & 23.72 & 12 \\
\hline 12 & $\begin{array}{l}\text { Least knowledge about the rules } \\
\text { and beneficial rights provided }\end{array}$ & 1873 & 37.46 & 10 \\
\hline
\end{tabular}

Non-availability of 100 days of work was the most critical constraint perceived under MGNREGA by the respondents, followed by late payment of wages, underpayment of wages, non-availability of tools, materials, and worksite facilities, no solution to complain, denial of an oral application, job card and passbook with implementing authority, selection of less priority or inappropriate work, unemployment allowance not provided, slightest knowledge about the rules and beneficial rights provided, no records in job card and non-acceptance of a written work application.

As per provisions laid down under the act to guaranteed 100 days of employment to every adult member of a household in a financial year was found to be lacking far and away from the actual number of guaranteed days. This is implied from the findings of Stina et al. (2015) where the average person-days generated during the study period was 46.13 days in Imphal East and 78.67 days in Churachandpur district.

Table 2: Constraints perceived by functionaries of MGNREGA affecting its desired performance $(\mathrm{N}=8)$

\begin{tabular}{|c|c|c|}
\hline $\begin{array}{l}\text { S1. } \\
\text { No. }\end{array}$ & Constraints & $\begin{array}{l}\text { Frequency } \\
(\%)\end{array}$ \\
\hline 1 & $\begin{array}{l}\text { Scarcity of funds and non acceptance of } \\
\text { labour budget }\end{array}$ & $8(100.00)$ \\
\hline 2 & $\begin{array}{l}\text { Delay/non release of fund during peak } \\
\text { period of employment demand }\end{array}$ & $2(25.00)$ \\
\hline 3 & Non availability of central share & $3(37.50)$ \\
\hline 4 & $\begin{array}{l}\text { Too many gates / entry point in the fund } \\
\text { flow from central to beneficiary }\end{array}$ & $3(37.50)$ \\
\hline 5 & Failing to upload MIS report timely & $8(100.00)$ \\
\hline 6 & $\begin{array}{l}\text { Low IEC campaign for the rights and duties } \\
\text { to the beneficiary }\end{array}$ & $6(75.00)$ \\
\hline 7 & Failing to produce utilisation certificate & $3(37.50)$ \\
\hline 8 & Lack of close monitoring at different level & $2(25.00)$ \\
\hline 9 & Insincerity of implementing agency & $1(12.50)$ \\
\hline 10 & $\begin{array}{l}\text { Permissible work not confirming to the } \\
\text { condition and nature of the state particularly } \\
\text { at GP level }\end{array}$ & $1(12.50)$ \\
\hline
\end{tabular}

Note: Figures in the parentheses indicate percentage.

Over and above, Stina et al. (2015) was also indicative of this constraint as the average annual income contributed from MGNREGA was found to be ₹ 1270/- only while the maximum earning achievable was ₹ $19000 /$ - per year. According to the MGNREGA guidelines, wages are to be paid according to the Minimum Wages Act 1948, and the payments for the work should be made within two weeks of the completion of the work. However, delay/ late in payment and underpayments were common problems under MGNREGA. The problem was also reported by Feroze et al. (2012) and Singh (2012). This delay can be two to three months, most commonly, and sometimes it takes five to six months to get the payment under MGNREGA. Moreover, the wages reported to be received by the beneficiaries were less than the wage rate fixed under MGNREGA as also highlighted by Techi and Sharma (2014) and Khawlneikim and Mital (2015). These issues related to the payment of wages 
pose a significant threat to the programme in achieving livelihood security.

Some of the critical constraints perceived by the functionaries of MGNREGA affecting its desired performance were scarcity of funds and nonacceptance of labor budget, failing to upload Management Information System (MIS) report timely, low Information Education Communication (IEC) campaign for the rights and duties to the beneficiary, nonavailability of central share, too many gates/entry point in the fund flow from central to the beneficiary, failing to produce utilization certificate, delay/non-release of the fund during the peak period of employment demand, lack of close monitoring at a different level, the insincerity of implementing agency, permissible work not conforming to the condition and nature of the state particularly at GP level.

As per the reports from the functionaries, scarcity of funds was the most hampering constraint as the labor budget prepared based on the number of job card holders prevailing in the area was not accepted by the central government, which sequentially leads to failure in providing 100 days of works. Institute of Applied Manpower Research (2008) also has mentioned issues like procedural flaws in technical estimates, the extent of autonomy in planning processes, and delay in procedures and processes. Failing to update and upload MIS report timely was also the main obstacle in achieving the desired performance of MGNREGA. Since the government accepts the labor budget and sanction funds based on the reports uploaded in MIS. Delay in data collection and tabulation, improper availability of internet facilities, inability to handle data and advance sophisticated Technology etc. might be some of the probable reasons as the training needed on maintenance of various records, MIS, MMS etc. were also found to be suggested by cent percent of the functionaries (Table 4). Due to more minor Information Education Communication (IEC)/ awareness campaign, various rights and duties bestowed for the beneficiary were not known, and thus level of accessibility, better functioning, and efficient employment was fewer. As a result, an increase in IEC campaign/ awareness was also found to be suggested by both beneficiaries as well as functionaries (table 3 and 4). The probable reason behind less IEC campaign might be improper utilization of funds allocated for organizing training, less or no fund allocation of for awareness campaign, no application from the respective gram panchayat to organize IEC/ awareness campaign to the state nodal agency which is solely responsible for organizing such campaign.

\section{Strategies for improvement of MGNREGA}

The suggestions given by the beneficiaries and functionaries under MGNREGA that will contribute to the better performance of the programs were identified and recorded and presented in Table 3 and 4, respectively.

Table 3: Suggestion according to the beneficiaries of $\operatorname{MGNREGA}(\mathrm{n}=100)$

\begin{tabular}{|c|c|c|}
\hline $\begin{array}{l}\text { Sl. } \\
\text { No. }\end{array}$ & Statements & $\begin{array}{l}\text { Frequency } \\
(\%)\end{array}$ \\
\hline 1 & Provision of 100 days work & $100(100.00)$ \\
\hline 2 & Timely and full payment of wages & $100(100.00)$ \\
\hline 3 & Provision of all the facilities & $84(84.00)$ \\
\hline 4 & $\begin{array}{l}\text { Direct transfer of wages from centre to job } \\
\text { card holder's account }\end{array}$ & $55(55.00)$ \\
\hline 5 & More awareness campaign & $35(35.00)$ \\
\hline 6 & $\begin{array}{l}\text { Exclusion of work division among MLA, ZP } \\
\text { and GP }\end{array}$ & $37(37.00)$ \\
\hline 7 & Work should be taken up priority wise & $13(13.00)$ \\
\hline 8 & $\begin{array}{l}\text { Provision of exact working days a job card } \\
\text { holder must receive in response to fund } \\
\text { allocated, with full payment of wages }\end{array}$ & $31(31.00)$ \\
\hline 9 & Sincerity of the implementing agency & $43(43.00)$ \\
\hline 10 & Provision of unemployment allowance & $25(25.00)$ \\
\hline
\end{tabular}

Note: Figures in the parentheses indicate percentage.

Cent percent of the beneficiaries suggested for provision of exact 100 days of works. Timely and complete payment of wages, followed by the provision of all the facilities viz., crèche, sheds, first aids, tools and implement required for performing the work etc. $(84.00 \%)$, similar suggestion on the establishment of crèche was also made in the studies conducted by Narayanan (2008). Moreover, the direct transfer of wages from center to the job card holder's account was also suggested by the 55.00 percent of beneficiaries. 
Perceived Constraints Affecting the Desired Performance of MGNREGA and Strategies for Improvement $\mathbb{J}_{\text {AESSRA }}$

As per a report from the beneficiaries, even though jobs were provided under MGNREGA, the -days generated was very low and far from guaranteed employment days. Wages were never paid within two weeks of -work completion, and some amount of wages were always deducted from the exact amount supposed to get at the time of payment. Thus, to overcome such situation, direct transfer of wages from the centre to the job card holders was also suggested by the beneficiaries, which is incorporated in the guidelines recently by the centre government and had started practicing in some part of India although not in Manipur. Various facilities like providing tools and materials, crèche for baby, sheds etc. were also found not provided at the work place, they have to take their own tools and implement, and for those who doesn't have were necessitate to buy which lead to increase in their material possession and babies brought by the working mothers were led out either on the road side or somewhere in a corner nearby the worksite.

Table 4: Suggestion according to MGNREGA functionaries $(\mathrm{n}=8)$

\begin{tabular}{|c|c|c|}
\hline $\begin{array}{l}\text { Sl. } \\
\text { No. }\end{array}$ & Particulars & $\begin{array}{l}\text { Frequency } \\
(\%)\end{array}$ \\
\hline 1 & $\begin{array}{l}\text { Coordination needed between centre and } \\
\text { state particularly PRI at ground level while } \\
\text { framing the permissible work }\end{array}$ & $1(12.50)$ \\
\hline 2 & $\begin{array}{l}\text { Effective implementation of direct benefit } \\
\text { transfer (DBT) }\end{array}$ & $6(75.00)$ \\
\hline 3 & More IEC campaign to increase awareness & $5(62.5)$ \\
\hline 4 & $\begin{array}{l}\text { Training needed on maintenance of various } \\
\text { records, MIS, MMS etc }\end{array}$ & $8(100.00)$ \\
\hline 5 & $\begin{array}{l}\text { Timely release of fund by the centre as per } \\
\text { the targeted labour budget }\end{array}$ & $8(100.00)$ \\
\hline 6 & $\begin{array}{l}\text { Need good commanding and sincere leader } \\
\text { at grass root level }\end{array}$ & $4(50.00)$ \\
\hline 7 & Subsequent monitoring at different level & $3(37.50)$ \\
\hline 8 & $\begin{array}{l}\text { Active participation of beneficiaries in any } \\
\text { training programme or Gram Shaba held }\end{array}$ & $6(75.00)$ \\
\hline
\end{tabular}

Note: Figures in the parentheses indicate the percentage.

The functionaries made eight different types of suggestion. The majority $(100.00 \%)$ reported there should be the timely release of funds by the center as per the targeted labor budget and training on maintenance of various records, MIS, MMS etc. are in need. While $(75.00 \%)$ of them felt that effective implementation of Direct Benefit Transfer (DBT) and active participation of beneficiaries in training programs or Gram Sabha meetings would further improve performance. (62\%) The official also mentioned that more Information Education Communication (IEC) campaigns or awareness campaigns are in need for achieving the desired performance of the program.

The fund's timely release as per the targeted budget was found necessary by the functionaries to achieve the desired performance. It will lead to the provision of guaranteed 100 days laid down by the Act. Training needs on maintenance of various records, MIS, MMS etc. on the other hand indirectly relates to the provision of guaranteed 100 days employment and ultimately effective performance of the programs, since the allocation of funds, evaluation of performance, monitoring etc was also done based on the MIS report uploaded by the respective state. The effective implementation of direct benefit transfer (DBT) links directly between the centre and the beneficiaries in allocating the wages to the respective bank account without any middlemen, bringing transparency and fully benefiting the needed poor. Inactive participation and lack of interest of beneficiaries in training program or Gram Sabha meetings were usually observed by the functionaries; thus, active participation of beneficiaries in training programme or Gram Sabha meetings was recommended to further improve performance. A similar recommendation of sustained, intelligent, and enthusiastic involvement and cooperation of the village community was also found in Sharma and Didiwania (2013).

\section{CONCLUSION}

The study's findings revealed that non-availability of 100 days of work, late payment of wages, underpayment of wages, non-availability of tools \& worksite facilities etc. were the constraints perceived by the beneficiaries under MGNREGA. At the same time, constraints perceived by the functionaries of MGNREGA were scarcity of funds and non-acceptance of labor budget, failing to upload Management Information System (MIS) report 
timely, and low Information Education Communication (IEC) campaign. Moreover, to counter the perceived constraints, suggestions made by the beneficiaries of MGNREGA were the provision of exact 100 days of works and timely and complete payment of wages, provision of all the facilities viz., crèche, and tools and implement required etc. at the worksite, direct transfer of wages from center to job card holder's account. On the other hand, a suggestion made by functionaries of MGNREGA to counteract the constraints perceived by the functionaries were a timely release of the fund as per the targeted labor budget, training on maintenance of various records, MIS, MMS etc., effective implementation of (DBT) and active participation of beneficiaries in a training program or Gram Sabha meetings, more IEC campaign or awareness will contribute in further improvement of MGNREGA.

\section{REFERENCES}

Feroze, S. M., Roy, A. and Singh, R. 2012. Some Issues of NREGS: Review of North Eastern States of India with Special Reference to Meghalaya. Indian J. Hill Farming, 25(2): 27-32.

GoI. 2013. Report on employment and unemployment survey, 2012-2013. Labour Bureau, Ministry of Labour and Employment, Govt. of India.

Hulme, D. and Shepherd, A. 2003. Conceptualizing Chronic Poverty. World Dev., 31: 403- 423.

Institute of Applied Manpower Research, 2008. All-India report on evaluation of NREGA: A survey of twenty districts. Institute of Applied Manpower Research (IAMR), Narela, Delhi, India.
Kaushik, R. 2007. Poverty Alleviation and Pro-Poor Growth in India. Asian Institute of Transport Development, New Delhi, First published.

Khawlneikim, S. and Mital, M. 2015. Socio-Economic Impact of Rural Employment Guarantee Scheme in Churachandpur District, Manipur: A Beneficiary Perspective. Int. J. Sci. Res., 4(12): 25-27.

Mabughi, N. and Selim, T. 2006. Poverty as Social Deprivation: A Survey. Rev. Soc. Econ., 64(2): 181-204.

Narayanan, S. 2008. Employment Guarantee, Women's Work and Childcare. Econ. Polit. Weekly, 49(9): 10-13.

Planning Commission, Government of India, 2013. Press Note on Poverty Estimates, 2011- 12, GoI, New Delhi.

Sharma, R. and Didwania, M. 2013. Performance Analysis of MGNREGA: A Case Study of District Jind. Zenith Int. J. Bus. Econ. Manage. Res., 3(8): 155-165.

Singh, H. 2012. Mahatma Gandhi National Rural Employment Guarantee Act (MGNREGA): Issues and challenges, Int. J. Res. Commer. Econ. Manag., 1: 136-140.

Stina, Kh., Sarkar, A. and Singh, R.J. 2015. A Study on the Performance of MGNREGA in Manipur. Int. J. S. Sc., 4(4): 297305.

Techi, S. and Sharma, A. 2014. A study on the knowledge and perceptions of beneficiaries towards MGNREGA in Doimukh panchayat of Papum Pare district of Arunachal Pradesh. Int. J. Adv. Res. Comput. Sci. Manage. Stud., 2(10): 13-18.

UNDP. 2011. Poverty Reduction and Livelihoods Promotion. http://www.in.undp.org /content/india/en/home/ourwork/ povertyreduction/overview. Accessed 27 July 2014.

World Bank. 2000. World Development Report 2000/1: Attacking Poverty. Oxford: Oxford University Press. 